\title{
Red Cells Genetically Deficient in Carbonic Anhydrase II Have Elevated Levels of a Carbonic Anhydrase Indistinguishable from Muscle CA III ${ }^{a}$
}

\author{
N. D. CARTER, ${ }^{b}$ R. HEATH, ${ }^{b}$ R. J. WELTY, ${ }^{c}$ \\ D. HEWETT-EMMETT, ${ }^{c}$ S. JEFFERY ${ }^{b}$ A. SHIELS, ${ }^{b}$ and \\ R. E. TASHIAN ${ }^{\circ}$ \\ ${ }^{b}$ Department of Child Health \\ St. George's Hospital Medical School \\ London SWI7 ORE England \\ c Department of Human Genetics \\ University of Michigan Medical School \\ Ann Arbor, Michigan 48109
}

Adult human red cells contain appreciable levels of two carbonic anhydrase (CA) isozymes, CA I (11.6 $\pm 2.3 \mathrm{mg} / \mathrm{g} \mathrm{Hb})$ and CA II $(1.8 \pm 0.3 \mathrm{mg} / \mathrm{g} \mathrm{Hb})$, as determined by radioimmunoassay (RIA). ${ }^{1}$ Recently, biochemical and immunological studies have demonstrated the presence of an additional red cell carbonic anhydrase with properties indistinguishable from skeletal muscle CA III ${ }^{2,3}$ It is present at levels of $147 \pm 17 \mu \mathrm{g} / \mathrm{g} \mathrm{Hb}$ assuming that the RIA, set up for the skeletal muscle CA III, ${ }^{4}$ is in fact detecting a CA isozyme in red cells immunologically indistinguishable from muscle CA III. Purification of this red cell "CA III" by the methods used for isolating skeletal muscle CA III (affinity chromatography and gel filtration $)^{5}$ has, however, resulted in yields of less than $10 \%$ of that expected. ${ }^{3}$ The purified red cell "CA III" and skeletal muscle CA III have identical elution properties from reverse-phase $\mu$ Bondapak $C_{18}$ high performance liquid chromatography (HPLC) columns ${ }^{5,6}$ and preliminary peptide-map data indicate that the allelic polymorphism found in skeletal muscle CA III (31 He $\rightarrow \mathrm{Val}^{5}$ is also present in the "CA III" purified from outdated red cells pooled from several individuals. These data and the finding that the characteristic electrophoretic mobilities of skeletal muscle CA III from different mammals are mimicked by their red cell "CA III" counterparts strongly support the view that we are examining products of the same gene. Future work at the gene level should confirm this. However, we must take into account that the phenomenon of gene conversion, whereby adjacent homologous genes can evolve "in concert" (e.g., $\alpha$ globin and $\gamma$ globin genes) ${ }^{7}$; this provides a basis for the possibility that there are two tissue-specific CA III genes encoding identical or almost identical proteins.

The CA I and CA II genes are closely linked on chromosome 3 of the mouse. ${ }^{8}$ There is good evidence for such linkage in the Old World monkey, Macaca nemestrina, ${ }^{9}$ and other mammals. ${ }^{10}$ It seems likely that CA I and CA II will also be linked in humans although only CA II has been mapped (to chromosome 8) so

\footnotetext{
${ }^{a}$ This work was supported by NIH grant GTM-24681 (R.E.T.) and the Muscular Dystrophy Association of Great Britain (N.D.C.).
} 
far. 11 This linkage is consistent with the cis-acting effect of a polymorphic CA I deficiency gene in Macaca nemestrina, which results in the almost complete absence of red cell CA I as well as the approximately $60 \%$ suppression of red cell CA II levels. ${ }^{9}$ The recent finding that CA II deficiency is the primary defect in the autosomal recessive syndrome of osteopetrosis with renal tubular acidosis and cerebral calcification ${ }^{12}$ has now been extended to 11 families, and in each case the levels of CA I in the homozygous CA II-deficient individual is somewhat elevated. ${ }^{13}$ Since the possible linkage of the CA III gene(s) to those for CA I and CA II has yet to be demonstrated, it seemed worthwhile to examine the "CA III" levels in the red cells of a Belgian family carrying the CA II deficiency gene. ${ }^{14}$ The results of the determination of CA I/CA II ratios by HPLC, ${ }^{6}$ CA I concentration by "rocket" immunoelectrophoresis (IE), ${ }^{15}$ and "CA III" by RIA" are shown in TABLE 1. While the data are preliminary and need to be extended to other families carrying the CA II deficiency gene, it appears that the CA III level is elevated by approximately $100 \%$ in the clinically affected CA II deficient son whereas the levels in the asymptomatic heterozygous parents and the heterozygous son seem close to the normal range. The normal range of human red cell CA I level is quite broad, ${ }^{1}$ and although the CA I level in the homozygous CA II-deficient son is the highest, it is within the normal range, even taking account of the fact that lower values are found with the "rocket" immunoelectrophoresis (IE) technique ${ }^{15}$ than the RIA procedure. ${ }^{4}$

TABLE 1. Erythrocyte Carbonic Anhydrase Levels in a Belgian Family Carrying CA II Deficiency Genes.

\begin{tabular}{lcccc}
\hline & $\begin{array}{c}\text { CA I/CA II } \\
\text { (HPLC) }\end{array}$ & $\begin{array}{c}\text { CA II } \\
\text { Assumed } \\
\text { Genotype }\end{array}$ & $\begin{array}{c}\text { CA I } \\
\text { mg/g Hb } \\
\text { (IE) }\end{array}$ & $\begin{array}{c}\text { CA III } \\
\mu \text { g/g Hb } \\
\text { (RIA) }\end{array}$ \\
\hline 1. Father & 18.8 & $+/ 0$ & 13.3 & 165.0 \\
2. Mother & 11.8 & $+/ 0$ & 11.4 & 217.3 \\
3. Son & $>10^{4}$ & $0 / 0$ & 15.2 & 333.1 \\
4. Son & 10.9 & $+/ 0$ & 8.8 & 188.0 \\
5. Son & 7.6 & $+/+$ & 10.6 & 170.5 \\
Mean $( \pm$ SE) control levels & $6.4 \pm 2.0^{13}$ & - & $11.6 \pm 2.3^{1}$ & $147 \pm 17^{2}$ \\
\hline
\end{tabular}

\section{ACKNOWLEDGMENTS}

We thank Drs. M. Vainsel (University of Brussels) and W. S. Sly (Washington University School of Medicine) for obtaining the blood samples from the Belgian family.

\section{REFERENCES}

1. Tashian, R. E. \& N. D. Carter. 1976. Biochemical genetics of carbonic anhydrase. In Advances in Human Genetics. Vol. 7: 1-55. H. Harris \& K. Hirschhorn, Eds. Plenum Press. New York.

2. Heath, R., N. D. Carter, D. Hewett-Emmett, E. Fincanci, S. Jeffery, A. SHIEls \& R. E. TASHIAN. 1983. Human erythrocytes contain a protein with properties indistinguishable from skeletal muscle carbonic anhydrase III. Fed. Proc. 42: 2180. 
3. Carter, N. D., R. Heath, D. Hewett-Emmett, R. J. Welty, E. Fincanci, S. JefFery, A. ShIEls \& R. E. TAShian. Carbonic anhydrase IIl in human erythrocytes. In preparation.

4. Heath, R., S. Jeffery \& N. Carter. 1982. Radioimmunoassay of human muscle carbonic anhydrase III in dystrophic states. Clin. Chim. Acta 119: 299-305.

5. Hewett-Emmett, D., R. J. Welty \& R. E. TAshian. 1983. A widespread silent polymorphism of human carbonic anhydrase III (31 Ile $\leftrightarrow$ Val): Implications for evolutionary genetics. Genetics 105: 409-420.

6. HeweTt-EMMETT, D. 1982. Analytical and preparative high performance liquid chromatography (HPLC) of the three human carbonic anhydrase isozymes and their tryptic peptides on reverse-phase columns. Fed. Proc. 41: 1385.

7. Hewett-Emmett, D., P. J. Venta \& R. E. Tashian. 1982. Features of gene structure, organization and expression that are providing unique insights into molecular evolution and systematics. In Macromolecular Sequences in Systematics and Evolutionary Biology. M. Goodman, Ed.: 357-405. Plenum Press. New York.

8. Eicher, E. M., R. H. Stern, J. E. Womack, M. T. Davisson, T. H. Roderick \& S. C. REYNOLDS. 1976. Evolution of mammalian carbonic anhydrase loci by tandem duplication: Close linkage of Car-1 and Car-2 to the centromere region of chromosome 3 of the mouse. Biochem. Genet. 14: 651-660.

9. DeSimone, J., M. Linde \& R. E. TAshian. 1973. Evidence for linkage of carbonic anhydrase isozyme genes in the pigtailed macaque, Macaca nemestrina. Nature (New Biol.) 242: 55-56.

10. Carter, N. D. 1972. Carbonic anhydrase isozymes in Cavia porcellus, Cavia aperea and their hybrids. Comp. Biochem. Physiol. (B) 43: 743-747.

11. Venta, P. J., T. B. Shows, P. J. Curtis \& R. E. Tashian. 1983. The polymorphic gene for human carbonic anhydrase II: A new molecular disease marker located on chromosome 8. Proc. Natl. Acad. Sci. USA 80: 4437-4440.

12. Sly, W. S., D. Hewett-Emmett, M. P. Whyte, Y.-S. L. Yu \& R. E. Tashian. 1983. Carbonic anhydrase II deficiency identified as the primary defect in the autosomal recessive syndrome of osteopetrosis with renal tubular acidosis and cerebral calcification. Proc. Natl. Acad. Sci. USA 80: 2752-2756.

13. Tashian, R. E., D. Hewett-Emmett, S. J. Dodgson, R. E. Forster, II \& W. S. SLY. 1984. The value of inherited deficiencies of human carbonic anhydrase isozymes in understanding their cellular roles. Ann. N.Y. Acad. Sci. 429: 262-275. This volume.

14. Vainsel, M., P. Fondu, S. Cadranel, C. Rocmans \& W. Gepts. 1972. Osteopetrosis associated with proximal and distal renal tubular acidosis. Acta Paediat. Scand. 61: $429-434$.

15. JefFery, S., Y. Edwards \& N. Carter. 1980. Distribution of CA III in fetal and adult human tissue. Biochem. Genet. 18: 843-849. 